\title{
Gaya Kepemimpinan dan Motivasi terhadap Kinerja Karyawan pada Bank BJB Cabang Tangerang
}

\author{
Ryani Dhyan Parashakti \\ Fakultas Ekonomi dan Bisnis, Universitas Mercu Buana, Jakarta Barat \\ e-mail:ryani@mercubuana.ac.id \\ Dede Irfan Setiawan \\ Fakultas Ekonomi dan Bisnis, Universitas Mercu Buana, Jakarta Barat \\ e-mail:mbemdede05@gmail.com
}

\begin{abstract}
This study aims to determine the effect of leadership style and motivation on employee performance. The object of this study are employees of Bank bjb Branch Tangerang. This study was conducted on 64 respondents using quantitative descriptive approach. Therefore, the analysis of the data used is the statistical analysis in the form of multiple linear regression.The results of this study addressed that in partial leadership style and motivation have a significant effect on employee performance. This is evidenced from the results of the partial test ( $t$ test) to address the significance of the two independent variables that support the hypothesis. Therefore, the test results on this study can be accepted by the statement that the influence of leadership style and motivation have a significant effect on employee performance bjb Bank Branch Tangerang.
\end{abstract}

Keywords: Styles of Leadership, Motivation, Employee Performance

\section{PENDAHULUAN}

Sumber daya manusia merupakan komponen utama suatu organisasi yang menjadi perencana dan pelaku aktif dalam setiap aktivitas organisasi. Mereka memiliki pikiran, perasaan, keinginan, status dan latar belakang pendidikan, usia, jenis kelamin yang heterogen yang dibawa ke dalam suatu organisasi sehingga tidak seperti mesin, uang dan material, yang sifatnya pasif dan dapat dikuasai dan diatur sepenuhnya dalam upaya mendukung tercapainya tujuan yang ingin dicapai organisasi.(Sudarmayanti, 2007).

Faktor yang dinilai paling menentukan keberhasilan suatu organisasi atau perusahaan adalah seorang pemimpin. Berhasil ataupun tidaknya seorang pemimpin memberikan motivasi kepada sumber daya manusia (SDM) untuk meningkatkan efektivitas kinerja yang dicapai perusahaan bergantung pada besar kecilnya perhatian yang diberikan untuk memenuhi kebutuhan yang memberikan semangat dan doronganya bagi bawahan agar menjadi lebih bergairah dalam melaksanakan pekerjaannya sesuai dengan tujuan yang diinginkan oleh perusahaan (Sudarmayanti, 2007; Fuad et al., 2017).

Kepemimpinan adalah perilaku di mana seseorang dapat memberikan motivasi kepada orang lain agar mau bekerja keras untuk mencapai tujuan sebuah perusahaan atau organisasi. Kepemimpinan merupakan jenis kemampuan yang dimiliki seseorang untuk dapat mempengaruhi orang lain agar mau bekerja keras untuk mencapai tujuan tertentu. Kepemimpinan merupakan kemampuan yang dimiliki seseorang untuk mempengaruhi orang lain agar mau bekerja mencapai tujuan dan saran (Hasibuan, 2009; Sudjiman, 2009).

Kepemimpinan memainkan peranan yang dominan dan krusial dalam keseluruhan upaya untuk meningkatkan kinerja baik pada 
tingkat individu, kelompok dan organisasi. Pemimpin yang berhasil adalah pemimpin yang mampu melaksanakan kepemimpinan secara efektif untuk tercapainya tujuan organisasi. Seorang pemimpin mempunyai peranan sangat penting dalam mempengaruhi sikap karyawan untuk rela melaksanakan pekerjaan dan dapat memberikan dampak positif maupun dampak negatif terhadap kinerja karyawan. Kepemimpinan mempunyai fungsi sebagai penggerak dan koordinator dari sumber daya manusia (Hasibuan, 2009).

Peranan seorang pemimpin memang sangatlah penting dalam usaha memotivasi bawahannya agar dapat meningkatkan efektivitas kerja perusahaan yang diinginkan. Seorang pemimpin di dalam usahanya meningkatkan motivasi kerja adalah dengan cara mengatur orang lain untuk menjalankan tugas-tugas yang memang diperlukan dan bisa bekerja dengan kelompok. Kepemimpinan seseorang tidak hanya dituntut untuk tugas dan sigap dalam menghadapi setiap persoalan yang ada, melainkan juga harus mengerti akan keinginan ataupun kebutuhan dari setiap karyawan. Hal ini dikarenakan pemimpin merupakan salah satu anggota kelompok yang paling berpengaruh terhadap aktivitas kelompoknya dan memainkan peran penting dalam merumuskan ataupun mencapai tujuantujuan kelompoknya (Hasibuan, 2009; Krisnadi \& Tarigan, 2016).

Setiap organisasi tentu ingin mencapai tujuan. Untuk mencapai tujuan tersebut, peranan manusia yang terlibat di dalamnya sangat penting. Untuk menggerakkan manusia agar sesuai dengan yang dikehendaki organisasi selain pemimpin adalah motivasi, maka haruslah dipahami motivasi manusia yang bekerja di dalam organisasi tersebut, karena motivasi inilah yang menentukan perilaku orang-orang untuk bekerja, atau dengan kata lain bahwa perilaku merupakan cerminan yang paling sederhana dari motivasi (Robbins \& Judge, 2007).

Bank BJB memberikan motivasi kepada karyawan dengan cara memberikan promosi atau kenaikan grade yang dilakukan dalam setahun untuk dua periode, sehingga karyawan bisa termotivasi dan bisa bekerja dengan baik yang selanjutnya akan bisa meningkatkan kinerja karyawan.

Tabel 1. Kehadiran Karyawan dari Tahun 2013 hingga September 2016

\begin{tabular}{cc}
\hline Tahun & Persentase \\
\hline 2013 & 94,1 \\
2014 & 93,5 \\
2015 & 96,4 \\
2016 & 93,8 \\
\hline
\end{tabular}

Sumber: HRD PT. Bank BJB Cabang Tangerang, 2016

Tabel 1 menujukan bahwa kehadiran karyawan pada Bank BJB Cabang Tangerang berfluktuasi pada setiap tahunnya. Dari data tersebut, terlihat bahwa sistem manajemen pada Bank bjb Cabang Tangerang mempunyai pemimpin yang memiliki gaya kepemimpinan yang baik, sehingga karyawan Bank bjb Cabang Tangerang termotivasi untuk bersedia berkinerja dalam menyelesaikan tugas dan pekerjaannya.

Kinerja karyawan berkaitan erat dengan gaya kepemimpinan yang diterapkan oleh atasannya. Jenis gaya kepemimpinan yang diterapkan dalam suatu organisasi dapat membantu memberikan dampak yang baik terhadap karyawannya terutama dalam rangka menciptakan kinerja yang optimal bagi karyawan itu. Adanya gaya kepemimpinan yang sesuai situasi dan kondisi organisasi maka karyawan akan lebih semangat dalam menjalankan tugas serta kewajibannya dan akan meningkatkan kemampuan karyawan dalam bekerja. Sehingga kinerja karyawan tersebut dapat maksimal dan sesuai dengan kompetensi yang ada dalam diri masingmasing karyawan (Wirawan, 2013). 
Pimpinan yang dapat menerapkan gaya kepemimpinan yang baik bisa meningkatkan kinerja karyawannya. Hal ini sesuai penelitian yang dikemukakan oleh (Arimbawa \& Dewi, 2013). Dalam kaitan dengan membentuk kinerja karyawan sesuai dengan apa yang diharapkan oleh perusahaan, maka peran gaya seorang pemimpin merupakan hal yang sangat perlu dipertimbangkan.

Selanjutnya agar karyawan dapat berkinerja dengan baik, maka selayaknya pihak perusahaan secara terus-menerus dapat memberikan motivasi pada para karyawannya demi keberlanjutan perusahaan untuk ke depannya. Pernyataan ini didukung oleh hasil penelitian dari Abdilah dan Djastuti (2011) yang menemukan bahwa motivasi dari perusahaan kepada para karyawan merupakan suatu hal yang berarti bagi karyawan untuk menyemangatkan mereka dalam bekerja.

Secara langsung dan tidak langsung gaya kepemimpinan yang digunakan oleh seorang pimpinan merupakan faktor yang perlu dipertimbangkan kepada bawahan untuk meningkatkan kinerja karyawan. Hal ini sesuai dengan hasil penelitian dari Agustina (2015) yang menyatakan bahwa baik faktor gaya kepemimpinan maupun motivasi merupakan suatu hal yang sangat penting dalam meningkatkan kinerja karyawan.

Berdasarkan uraian dari latar belakang tersebut, maka peneliti dapat menyimpulkan pokok permasalahannya dengan mengajukan topic penelitian mengenai pengaruh gaya kepemimpinan dan motivasi terhadap kinerja karyawan pada Bank BJB Cabang Tangerang. Dari pokok permasalahan, maka rumusan permasalahan penelitian ini yaitu: (1) Apakah gaya kepemimpinan berpengaruh signifikan terhadap kinerja karyawan?; dan, (2) Apakah motivasi berpengaruh signifikan terhadap kinerja karyawan?. Sedangkan tujuan dalam penelitian ini adalah untuk melakukan analisis mengenai derajat signifikansi pengaruh dari gaya kepemimpinan atas kinerja karyawan, dan untuk mengetahui derajat signifikan dari pengaruh motivasi terhadap kinerja karyawan.

\section{Gaya Kepemimpinan}

Menurut Rivai (2008), gaya artinya sikap, gerakan, tingkah laku, sikap yang elok, gerak-gerik yang bernilai bagus, kekuatan, kesanggupan untuk berbuat baik. Anoraga (dalam Sutrisno, 2010) serta Hartanto (2016) mengemukakan bahwa kepemimpinan adalah kemampuan untuk mempengaruhi pihak lain melalui komunikasi baik langsung maupun tidak langsung dengan maksud untuk menggerakkan orang-orang agar dengan penuh pengertian, kesadaran, dan senang hati bersedia mengikuti kehendak pimpinan itu.

\section{Faktor-Faktor yang Mempengaruhi Gaya Kepemimpinan}

Dalam upaya mempengaruhi individu atau sekelompok individu, Luthans (2009) mengemukakan adanya empat faktor yang mempengaruhi gaya kepemimpinan, yaitu:

1. Karisma: memberikan visi dan misi, memunculkan rasa bangga, mendapatkan respek dan kepercayaan.

2. Inspirasi: mengkomunikasikan harapan tinggi, menggunakan simbol-simbol untuk memfokuskan usaha, mengekspresikan ada tujuan penting dalam cara yang sederhana.

3. Simulasi intelektual dapat: menunjukkan intelegensi, rasional, pemecahan masalah secara hati-hati.

4. Memerhatikan staf secara individu: bisa menunjukkan perhatian terhadap pribadi, memperlakukan karyawan secara individual, melatih, menasehati.

\section{Dimensi dan Indikator dari Gaya Kepemimpinan}

1. Kepemimpinan Otoriter.

Kepemimpinan otoriter adalah jika kekuasaan atau wewenang, sebagian besar mutlak tetap berada pada pemimpin atau kalau pimpinan itu menganut sistem sentralisasi wewenang. Proses pengambilan keputusan dan kebijaksanaan hanya ditetapkan sendiri oleh sang pemimpin, bawahan tidak diikutsertakan memberikan saran, ide dan pertimbangan dalam proses pengambilan keputusan. 
2. Kepemimpinan Delegatif

Kepemimpinan delegatif apabila seorang pemimpin melakukan delegasi wewenang kepada bawahan dengan lengkap. Dengan demikian, bawahan bisa mengambil keputusan dan kebijaksanaan dengan bebas atau leluasa di dalam melaksanakan pekerjaannya. Pemimpin tidak peduli cara bawahan mengambil keputusan dan mengerjakan pekerjaannya, sepenuhnya diserahkan kepada bawahan.

3. Kepemimpinan Partisipatif

Kepemimpinan partisipatif adalah bila dalam kepemimpinannya dilakukan dengan cara persuasif, menciptakan kerja sama yang serasi, menumbuhkan rasa loyalitas, dan partisipatif para bawahan. Pemimpin memotivasi bawahan agar merasa ikut memiliki perusahaan.

\section{Motivasi}

Sikap mental karyawan haruslah memiliki sikap mental yang siap sedia secara psikofisik (siap secara mental, fisik, situasi dan tujuan). Artinya, karyawan dalam bekerja secara mental siap, fisik sehat, memahami situasi dan kondisi serta berusaha keras mencapai target kerja (tujuan utama organisasi).

Menurut Terry G. (dalam Notoatmodjo, 2009), motivasi adalah keinginan yang terdapat pada diri seseorang individu yang mendorongnya untuk melakukan perbuatanperbuatan (perilaku). Menurut Stoner (dalam Notoatmodjo, 2009), motivasi adalah sesuatu hal yang menyebabkan dan yang mendukung tindakan atau perilaku seseorang. Sedangkan menurut Duncan (dalam Notoatmodjo, 2009) mengemukakan bahwa motivasi adalah setiap usaha yang didasarkan untuk mempengaruhi perilaku seseorang dalam meningkatkan tujuan organisasi semaksimal mungkin. Dari definisi-definisi menurut pendapat para ahli tersebut, maka dapat disimpulkan bahwa motivasi merupakan dorongan baik berasal dari dalam diri seseorang maupun yang berasal dari luar yang menggerakkan seseorang melaksanakan pekerjaan untuk dapat mencapai tujuan yang diinginkan perusahaan atau organisasi.

\section{Faktor-Faktor yang Mempengaruhi Motivasi}

Menurut Sutrisno (2010), motivasi sebagai proses psikologi dalam diri seseorang akan dipengaruhi oleh beberapa faktor. Faktor-faktor tersebut dapat dibedakan atas faktor internal dan eksternal yang berasal dari karyawan. Uraian dari masing-masing faktor tersebut adalah sebagai berikut.

1. Faktor Internal.

Faktor internal yang dinilai dapat mempengaruhi pemberian motivasi pada seseorang yaitu:

a. Keinginan untuk dapat hidup. Tipe keinginan untuk bisa hidup merupakan kebutuhan setiap manusia yang hidup di muka bumi ini. Kehidupan untuk dapat hidup meliputi kebutuhan untuk, memperoleh kompensasi yang dinilai memadai, kondisi kerja yang aman dan nyaman.

b. Keinginan untuk dapat memiliki. Tipe keinginan untuk dapat memiliki benda dapat mendorong seseorang untuk mau melakukan pekerjaan. Hal ini banyak kita alami dalam kehidupan kita seharihari, bahwa keinginan yang keras untuk dapat memiliki itu dapat mendorong orang untuk mau bekerja.

c. Keinginan memperoleh penghargaan. Seseorang ingin bekerja disebabkan adanya keinginan untuk diakui, dihormati orang lain. Untuk memperoleh status sosial yang lebih tinggi, orang ingin mengeluarkan uangnya, untuk memperoleh uang itu pun ia harus bekerja keras.

d. Keinginan untuk dapat memperoleh pengakuan. Bila kita perinci, maka keinginan memperoleh pengakuan itu dapat meliputi hal-hal:

- Adanya penghargaan terhadap prestasi.

- Adanya hubungan kerja yang harmonis dan kompak.

- Pimpinan yang adil dan bijaksana.

- Perusahaan tempat bekerja dihargai oleh masyarakat. 


\section{Faktor Eksternal.}

Faktor eksternal juga tidak kalah peranannya dalam melemahkan motivasi kerja seseorang. Faktor-faktor eksternal itu adalah:

a. Kondisi lingkungan kerja merupakan keseluruhan sarana dan prasarana kerja yang ada di sekitar karyawan yang sedang melakukan pekerjaan yang bisa mempengaruhi pelaksanaan pekerjaan. Lingkungan kerja ini, meliputi tempat kerja, fasilitas dan alat bantu pekerjaan, kebersihan, pencahayaan, ketenangan, termasuk juga hubungan kerja antara orang-orang yang ada di tempat tersebut.

b. Kompensasi yang dianggap memadai. Kompensasi merupakan salah satu sumber penghasilan utama bagi para karyawan untuk menghidupi diri beserta keluarganya. Kompensasi yang memadai merupakan alat motivasi yang paling ampuh bagi perusahaan untuk mendorong para karyawan bekerja dengan baik.

c. Supervisi yang baik. Fungsi supervisi dalam suatu pekerjaan adalah memberikan pengarahan, membimbing kerja para karyawan, agar dapat melaksanakan kerja dengan baik tanpa membuat kesalahan. Dengan demikian, posisi supervisi sangat dekat dengan para karyawan, dan selalu menghadapi para karyawan dalam melaksanakan tugas sehari-hari.

d. Adanya jaminan pekerjaan. Setiap orang akan mau bekerja mati-matian mengorbankan apa yang ada pada dirinya untuk perusahaan, kalau yang bersangkutan merasa ada jaminan karier yang jelas dalam melakukan pekerjaan.

e. Status dan tanggung jawab. Status atau kedudukan dalam jabatan tertentu merupakan dambaan setiap karyawan dalam bekerja. Mereka bukan hanya mengharapkan kompensasi semata, tapi pada satu masa mereka juga berharap akan dapat kesempatan menduduki jabatan dalam suatu perusahaan. f. Peraturan yang fleksibel. Bagi suatu perusahaan besar, biasanya sudah ditetapkan sistem dan prosedur kerja yang harus dipatuhi oleh seluruh karyawan. Sistem dan prosedur kerja ini dapat kita sebut dengan peraturan yang berlaku dan bersifat mengatur dan melindungi para karyawan.

\section{Dimensi Motivasi}

Abraham H. Maslow dengan Teori Hierarki merupakan teori motivasi yang dikembangkannya dengan mengemukakan bahwa kebutuhan manusia tersebut dapat diklasifikasikan ke dalam lima hierarki (Sutrisno, 2010). Kelima hiirarki .kebutuhan tersebut yaitu:

1. Kebutuhan Fisiologis (Physiological Needs). Tipe kebutuhan ini untuk mempertahankan hidup dari kematian. Kebutuhan ini merupakan tingkat paling dasar yang diperkenalkan oleh Maslow. Kebutuhan ini berupa kebutuhan akan makan, minum, perumahan, pakaian, yang harus dipenuhi oleh seseorang dalam upayanya untuk mempertahankan diri dari kelaparan, kehausan, kedinginan, kepanasan, dan sebagainya.

2. Kebutuhan Rasa Aman (Safety Needs). Menurut Maslow, setelah kebutuhan tingkat dasar terpenuhi, maka seseorang berusaha memenuhi kebutuhannya yang lebih tinggi, yaitu kebutuhan akan rasa aman dan keselamatan.

3. Kebutuhan Hubungan Sosial (Affiliation Needs). Kebutuhan ini merupakan kebutuhan tingkat ketiga dari Maslow. Kebutuhan ini merupakan kebutuhan untuk hidup bersama dengan orang lain. Kebutuhan ini hanya dapat terpenuhi bersama masyarakat, karena hanya orang lainlah yang dapat memenuhinya, bukan diri sendiri.

4. Kebutuhan Pengakuan (Esteem Needs). Setiap orang yang normal membutuhkan adanya penghargaan diri dan penghargaan prestise diri dari lingkungannya. Semakin tinggi status dan kedudukan seseorang dalam perusahaan, maka semakin tinggi kebutuhan prestise yang bersangkutan. 
5. Kebutuhan Aktualisasi Diri (Self Actualization). Kebutuhan aktualisasi diri merupakan tingkat kebutuhan yang paling tinggi. Untuk memenuhi kebutuhan puncak ini biasanya seseorang bertindak bukan berdasarkan dorongan orang lain, tetapi karena kesadaran dan keinginan diri sendiri.

\section{Indikator Motivasi}

Ada beberapa indikator yang digunakan untuk mengukur motivasi dalam sebuah organisasi (Sutrisno, 2010). Indikatorindikator tersebut sebagai berikut:

1. Pemberian gaji.

2. Pemberian bonus.

3. Fasilitas keamanan dan keselamatan kerja.

4. Diterima dalam kelompok.

5. Kebutuhan akan perasaan ikut serta.

6. Kebutuhan akan penghargaan diri.

7. Pengakuan akan prestasi.

8. Kemampuan.

9. Keterampilan.

\section{Pengertian Kinerja Karyawan}

Menurut Rivai dan Sagala (2010), kinerja merupakan perilaku nyata yang ditampilkan setiap orang sebagai prestasi kerja yang dihasilkan oleh karyawan sesuai dengan perannya dalam perusahaan. Menurut Mangkunegara (2009), kinerja karyawan merupakan istilah yang berasal dari $J o b$ Performance atau Actual Performance (prestasi kerja atau prestasi sesungguhnya yang dicapai seseorang). Berdasarkan pendapat para ahli tersebut, maka dapat disimpulkan bahwa kinerja karyawan adalah prestasi kerja atau hasil kerja (output) baik kualitas maupun kuantitas yang dicapai karyawan persatuan periode waktu dalam melaksanakan tugas kerjanya sesuai dengan tanggung jawab yang diberikan kepadanya.

\section{Faktor-faktor yang Mempengaruhi Kinerja Karyawan}

Menurut Simamora yang dikemukakan kembali oleh Mangkunegara (2010), faktorfaktor yang mempengaruhi pencapaian kinerja adalah:
1. Faktor individual yang terdiri dari: (a) Kemampuan dan keahlian; (b) Latar belakang; dan, (c) Demografi.

2. Faktor psikologis yang terdiri dari: (a) Persepsi; (b) Sikap; (c) kepribadian; (d) Pembelajaran; dan, (e) Motivasi.

3. Faktor organisasi yang terdiri dari: (a) Sumber daya; (b) Kepemimpinan; (c) Penghargaan; (d) Struktur; dan (e) Job design.

\section{Dimensi dan Indikator Kinerja}

Wirawan (2013) mengelompokkan dimensi kinerja karyawan menjadi tiga jenis: hasil kerja, perilaku kerja sifat pribadi yang ada hubungannya dengan pekerjaan. Kelompok-kelompok tersebut adalah:

1. Hasil Kerja.

Kuantitas serta kualitas kerja dari karyawan dalam melaksanakan aktivitas pekerjaannya. Hasil kerja dalam bentuk barang dan jenis yang dapat diukur jumlah atau kuantitas dan kualitasnya. Indikator yang digunakan adalah kecepatan dalam melaksanakan tugas dan efektivitas melaksanakan tugas.

2. Perilaku kerja.

Ketika berada di tempat kerja dan melaksanakan pekerjaannya, karyawan melakukan dua jenis perilaku kerja dan perilaku pribadinya. Indikator yang digunakan adalah disiplin kerja, profesionalisme, dan kerja sama.

3. Sifat pribadi yang ada hubungannya dengan pekerjaan.

Sifat ini adalah sifat pribadi yang diperlukan oleh seorang karyawan dalam melaksanakan pekerjaannya. Indikator yang digunakan adalah keterampilan, pengetahuan, dan kejujuran.

\section{Rerangka Pemikiran}

Pengaruh Gaya Kepemimpinan terhadap Kinerja Karyawan

Dalam suatu organisasi fungsi dan peran pemimpin dalam mendorong pembentukan organisasi yang diharapkan menjadi dominan. Menurut Fahmi (2013) bahwa kepemimpinan memiliki pengaruh besar dalam mendorong peningkatan kinerja karyawannya. Menurut 
Fahmi (2013), karyawan adalah satu bentuk aset internal yang paling berharga dimiliki oleh perusahaan. Artinya dengan kebijakan dan usaha kuat untuk selalu menjaga dan mempertahankan karyawan maka diharapkan akan mampu menghindari faktor-faktor yang mengakibatkan tidak tercapainya tujuan organisasi.

Peningkatan kualitas kinerja dari bawahan memiliki pada penciptaan kualitas kerja sesuai dengan pengharapan. Artinya para mitra bisnis dan konsumen akan menyukai hasil yang telah dihasilkan, dan ini berdampak pada peningkatan perolehan keuntungan perusahaan khususnya. Perolehan keuntungan artinya kinerja yang di hasilkan adalah telah tercapai sesuai harapan.

\section{Pengaruh Motivasi terhadap Kinerja} Karyawan

Motivasi merupakan sebuah keahlian dalam mengarahkan karyawan pada tujuan organisasi agar mau bekerja dan berusaha sehingga keinginan para karyawan dan tujuan organisasi dapat tercapai. Motivasi seseorang melakukan suatu pekerjaan karena adanya suatu kebutuhan hidup yang harus dipenuhi. Kebutuhan ini dapat berupa kebutuhan ekonomis, yaitu untuk memperoleh uang, sedangkan kebutuhan non-ekonomis dapat diartikan sebagai kebutuhan memperoleh penghargaan dan keinginan untuk maju.
Dengan segala kebutuhan tersebut, seseorang dituntut untuk lebih giat dan aktif dalam bekerja, untuk mencapai hal ini diperlukan adanya motivasi dalam melakukan pekerjaan, karena dapat mendorong seseorang bekerja dan selalu berkeinginan untuk melanjutkan usahanya.

Oleh karena itu, jika pegawai yang mempunyai motivasi kerja yang tinggi biasanya mempunyai kinerja yang tinggi pula. Mc Cleland et al. (dalam Mangkunegara, 2010) menyimpulkan bahwa ada hubungan yang positif antara motivasi dengan pencapaian kinerja. Artinya, pimpinan, manajer dan pegawai yang mempunyai motivasi berprestasi tinggi akan mencapai kinerja tinggi, dan sebaliknya mereka yang kinerjanya rendah disebabkan karena motivasi kerjanya rendah. Hal ini berarti bahwa setiap peningkatan motivasi kerja pegawai akan memberikan peningkatan yang sangat berarti bagi peningkatan kinerja karyawan dalam melaksanakan pekerjaannya.

Berdasarkan pada rumusan masalah, tujuan penelitian, hubungan antar variabel, dan hasil penelitian terdahulu sebagai dasar bukti empiris dalam penelitian ini, yang dijadikan sebagai pijakan oleh peneliti, maka dapat dinyatakan rerangka berpikir penelitian ini sebagaimana Gambar 1 ..

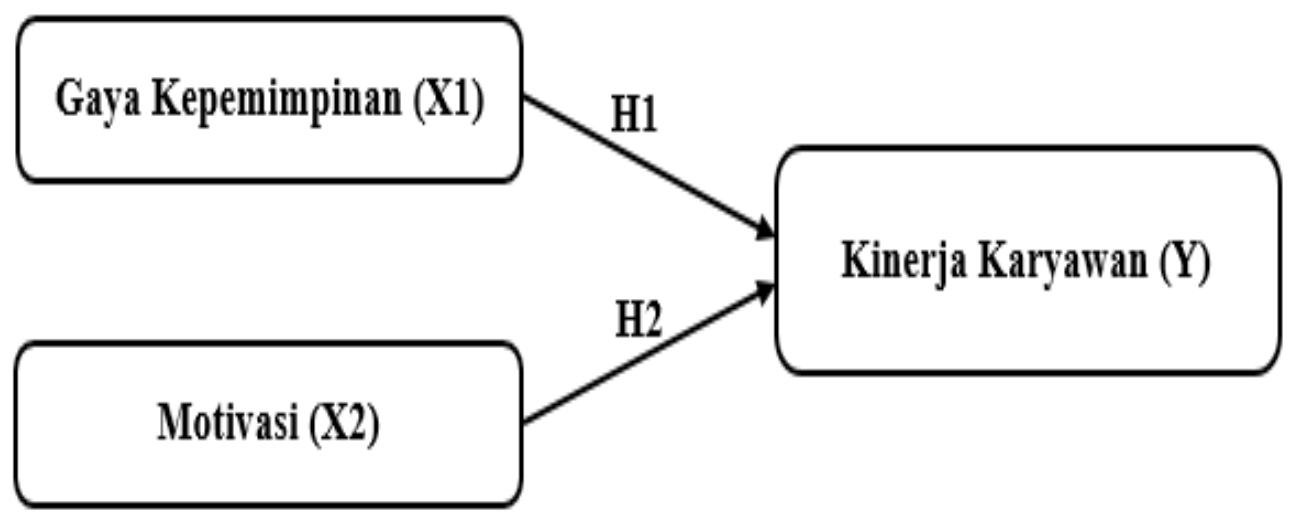

Gambar 1. Rerangka Pemikiran

Sumber: Diolah peneliti, 2018. 


\section{Hipotesis}

Berdasarkan rumusan dan tujuan dari penelitian, maka hipotesis dalam penelitian ini adalah:

H1: Gaya kepemimpinan memiliki pengaruh signifikan terhadap kinerja karyawan.

$\mathrm{H} 2$ : Motivasi memiliki pengaruh signifikan terhadap kinerja karyawan.

\section{METODE PENELITIAN \\ Populasi dan Sampel}

Populasi penelitian ini adalah semua karyawan Bank BJB Cabang Tangerang yang berjumlah 180 orang.

Penentuan jumlah sampel di dalam penelitian ini adalah menggunakan rumus Slovin, yaitu:

$$
\begin{aligned}
& \mathrm{n}=180 / 1+\left[(180)(0,1)^{2}\right] \\
& \mathrm{n}=180 / 2,8 \\
& \mathrm{n}=64,285
\end{aligned}
$$

Dengan demikian, total jumlah sampel yang digunakan dalam penelitian ini sebanyak 64 orang. Selanjutnya, peneliti menggunakan teknik covenience sampling dalam melakukan pengumpulan data studi melalui instrumen kuesioner. Menurut Sugiyono (2012), convenience sampling merupakan teknik penentuan sampel dimana karyawan yang dijadikan responden adalah karyawan yang berada di lokasi penelitian pada saat proses penyebaran kuesioner berjalan, dan bersedia menjadi responden.

\section{Definisi Operasional Variabel}

Dalam penelitian ini digunakan dua variabel independen dan satu variabel dependen. Variabel independen meliputi Gaya Kepemimpinan (X1) dan Motivasi (X2); sementara variabel dependen adalah Kinerja Karyawan (Y). Uraian dari masing-masing

\begin{tabular}{|c|c|c|c|}
\hline Variabel & Dimensi & Indikator & Skala \\
\hline \multirow{4}{*}{$\begin{array}{c}\text { Gaya } \\
\text { Kepemimpinan }\end{array}$} & $\begin{array}{l}\text { Kepemimpinan } \\
\text { Otoriter }\end{array}$ & $\begin{array}{l}\text { a. Wewenang mutlak terpusat } \\
\text { pada pimpinan } \\
\text { b. Keputusan selalu dibuat } \\
\text { oleh pimpinan } \\
\text { c. Tidak ada kesempatan bagi } \\
\text { bawahan untuk memberikan } \\
\text { saran. }\end{array}$ & \multirow{4}{*}{ Ordinal } \\
\hline & $\begin{array}{l}\text { Kepemimpinan } \\
\text { Delegatif }\end{array}$ & $\begin{array}{l}\text { a. Pimpinan melimpahkan } \\
\text { wewenang lebih banyak } \\
\text { kepada bawahan }\end{array}$ & \\
\hline & & $\begin{array}{l}\text { b. Kebijaksanaan banyak } \\
\text { dibuat oleh para bawahan } \\
\text { c. Keputusan lebih banyak } \\
\text { dibuat oleh para bawahan }\end{array}$ & \\
\hline & $\begin{array}{l}\text { Kepemimpinan } \\
\text { Partisipatif }\end{array}$ & $\begin{array}{l}\text { a. Menciptakan kerja sama } \\
\text { yang serasi } \\
\text { b. Menumbuhkan loyalitas } \\
\text { c. Pemimpin memotivasi } \\
\text { bawahan }\end{array}$ & \\
\hline
\end{tabular}
variabel itu dinyatakan pada Tabel 2, 3 dan 4.

Tabel 2. Definisi Operasional dari Gaya Kepemimpinan (X1)

Sumber: Hasibuan, 2009. 
Tabel 3. Definisi Operasional dari Motivasi (X2)

\begin{tabular}{|c|c|c|c|}
\hline Variabel & Dimensi & Indikator & Skala \\
\hline \multirow{5}{*}{ Motivasi } & $\begin{array}{l}\text { 1. Kebutuhan } \\
\text { fisiologis }\end{array}$ & $\begin{array}{l}\text { a. Pemberian gaji } \\
\text { b. Pemberian bonus }\end{array}$ & \multirow{5}{*}{ Ordinal } \\
\hline & $\begin{array}{l}\text { 2. Kebutuhan rasa } \\
\text { aman }\end{array}$ & $\begin{array}{ll}\text { a. } & \text { Fasilitas keamanan dan } \\
\text { keselamatan kerja }\end{array}$ & \\
\hline & $\begin{array}{l}\text { 3. Kebutuhan } \\
\text { hubungan sosial }\end{array}$ & $\begin{array}{l}\text { a. Diterima dalam kelompok } \\
\text { b. Kebutuhan akan perasaan } \\
\text { ikut serta }\end{array}$ & \\
\hline & $\begin{array}{l}\text { 4. Kebutuhan } \\
\text { pengakuan }\end{array}$ & $\begin{array}{l}\text { a. Kebutuhan akan } \\
\text { penghargaan diri } \\
\text { b. Pengakuan akan prestasi }\end{array}$ & \\
\hline & $\begin{array}{l}\text { 5. Kebutuhan } \\
\text { aktualisasi diri }\end{array}$ & $\begin{array}{l}\text { a. Kemampuan } \\
\text { b. Keterampilan }\end{array}$ & \\
\hline
\end{tabular}

Sumber: Maslow (dalam Sutrisno, 2010).

Tabel 4. Definisi Operasional dari Kinerja Karyawan (Y)

\begin{tabular}{|c|c|c|c|}
\hline Variabel & Dimensi & Indikator & Skala \\
\hline \multirow{4}{*}{$\begin{array}{l}\text { Kinerja } \\
\text { Karyawan }\end{array}$} & 1. Hasil kerja & $\begin{array}{l}\text { a. Ketepatan waktu } \\
\text { b. Baik dan benar }\end{array}$ & \multirow{4}{*}{ Ordina } \\
\hline & 2. Perilaku kerja & a. Disiplin kerja & \\
\hline & & $\begin{array}{l}\text { b. Profesionalisme } \\
\text { c. Kerja sama }\end{array}$ & \\
\hline & 3. Sifat Pribadi & $\begin{array}{l}\text { a. Keterampilan } \\
\text { b. Pengetahuan } \\
\text { c. Kejujuran }\end{array}$ & \\
\hline
\end{tabular}

Sumber: Wirawan, 2013.

Tabel 5. Hasil Uji Reliabilitas

\begin{tabular}{lcc}
\hline \multicolumn{1}{c}{ Variabel } & Cronbach's Alpha & Keterangan \\
\hline Gaya Kepemimpinan (X1) & 0,688 & Reliabel \\
Motivasi (X2) & 0,679 & Reliabel \\
Kinerja Karyawan (Y) & 0,635 & Reliabel \\
\hline
\end{tabular}

Sumber: Data primer diolah, 2018.

\section{HASIL ANALISIS}

\section{Hasil Uji Reliabiltas}

Uji ini dilakukan dengan menghitung besarnya Cronbach's Alpha untuk masingmasing instrumen kuesioner yang akan diuji. Berdasarkan hasil uji reliabilitas atas variabelvariabel penelitian ini yang dirangkum dalam Tabel 5, menujukan bahwa semua nilai
Cronbach's Alpha untuk setiap variabel adalah $\geq 0,60$. Dengan demikian, dapat disimpulkan dari masing-masing variabel dalam penelitian ini adalah reliabel.

\section{Hasil Analisis Regresi Linier Berganda}

Analisis regresi linier berganda dilakukan untuk mengetahui ada tidaknya pengaruh 
variabel independen terhadap variabel dependen. Berdasarkan hasil analisis regresi linier berganda pada Tabel 6, diperoleh model persamaan matematis untuk penelitian ini:

$$
\mathrm{Y}=5,503+0,429 \mathrm{X} 1+0,332 \mathrm{X} 2
$$

Berdasarkan atas persamaan matematis regresi linier berganda tersebut maka dapat diinterpretasikan sebagai berikut.

a. Koefisien variabel gaya kepemimpinan sebesar 0,429 memiliki arti bahwa gaya kepemimpinan memiliki pengaruh positif terhadap kinerja karyawan.

b. Koefisien variabel motivasi sebesar 0,0331 berarti bahwa motivasi memiliki pengaruh positif atas kinerja karyawan. c. Koefisien variabel gaya kepemimpinan lebih besar mempengaruhi variabel motivasi dibandingkan dengan koefisien variabel kinerja karyawan, yaitu sebesar 0,429 .

\section{Hasil Uji Statistik F (Uji Simultan)}

Uji F dilakukan untuk menguji apakah semua variabel independen yang dimasukkan ke dalam model mempunyai pengaruh secara bersama-sama (simultan) terhadap variabel dependen. Berdasarkan Tabel 7 dinyatakan hasil uji $F$ sebesar 64,314 dengan tingkat signifikansi $0,000<\alpha(0,05)$. Hasil ini menyatakan arti bahwa secara simultan gaya kepemimpinan dan motivasi berpengaruh signifikan terhadap kinerja karyawan.

Tabel 6. Hasil Regresi Linier Berganda

\begin{tabular}{llrrr}
\hline & & \multicolumn{2}{c}{$\begin{array}{c}\text { Unstandardized } \\
\text { Coefficients }\end{array}$} & $\begin{array}{c}\text { Standardized } \\
\text { Coefficients }\end{array}$ \\
\cline { 3 - 5 } Model & & \multicolumn{1}{c}{ B } & Std. Error & Beta \\
\hline 1 & (Constant) & 5,503 & 2,784 & \\
& Gaya_Kepemimpinan &, 429 &, 080 &, 542 \\
& Motivasi &, 331 &, 095 &, 350 \\
\hline
\end{tabular}

a. Dependent Variable: Kinerja_Karyawan

Sumber: Data primer diolah, 2018.

Tabel 7. Hasil Uji F (Uji Simultan)

\begin{tabular}{llcc}
\hline Model & & F & Sig. \\
\hline 1 & Regression & 64,314 &, $000^{\mathrm{b}}$ \\
& Residual & & \\
& Total & & \\
\hline
\end{tabular}

Sumber: Data primer diolah, 2018.

Tabel 8. Hasil Uji t (Uji Parsial)

\begin{tabular}{llrr}
\hline Model & & $\mathrm{t}$ & \multicolumn{2}{c}{ Sig. } \\
\hline 1 & (Constant) & 1,976 &, 053 \\
& Gaya_Kepemimpinan & 5,388 &, 000 \\
& Motivasi & 3,480 &, 001 \\
\hline
\end{tabular}

a. Dependent Variable: Kinerja_Karyawan

Sumber: Data primer diolah, 2018. 


\section{Hasil Uji Statistik t (Parsial)}

Uji t dilakukan dengan tujuan untuk mengukur seberapa jauh pengaruh dari setiap variabel independen secara individual dalam menerangkan variabel dependen. Berdasarkan pada Tabel 8, hasil uji t menyatakan bahwa pengaruh secara parsial dari masing-masing variabel adalah:

a. Pada variabel gaya kepemimpinan diperoleh nilai $t_{\text {hitung }}$ sebesar 5,388 dengan tingkat signifikansi 0,000 ; dimana $t_{\text {hitung }}$ $5,388>t_{\text {tabel }} 1,296$ dan tingkat signifikansi sebesar $0,000<0,1$. Artinya, secara parsial gaya kepemimpinan berpengaruh secara signifikan atas kinerja karyawan.

b. Pada variabel motivasi diperoleh nilai $t_{\text {hitung }}$ sebesar 3,480 dengan tingkat signifikansi 0,001 ; dimana nilai $t_{\text {hitung }}$ $3,480>t_{\text {tabel }} 1,296$ dan tingkat signifikansi sebesar $0,001<0,1$. Artinya, secara parsial motivasi berpengaruh signifikan terhadap kinerja karyawan.

\section{Pembahasan}

Pengaruh Gaya Kepemimpinan terhadap Kinerja Karyawan

Berdasarkan hasil uji signifikansi parsial (uji statistik t), maka hipotesis dalam penelitian ini dapat diterima, yaitu bahwa "gaya kepemimpinan berpengaruh signifikan terhadap kinerja karyawan". Hasil penelitian ini didukung oleh Paracha et al. (2013) serta Roscahyo (2013) bahwa gaya kepemimpinan berpengaruh signifikan terhadap kinerja karyawan. Hal ini juga sesuai dengan studi milik Amalia et al. (2016); Iqbal et al. (2015), serta Babatunde dan Emem (2015), yang menyatakan bahwa gaya kepemimpinan memiliki pengaruh signifikan terhadap kinerja karyawan.

\section{Pengaruh Motivasi terhadap Kinerja Karyawan}

Berdasarkan hasil uji signifikansi parsial (uji statistik t), hipotesis dalam penelitian ini dapat diterima, yaitu "motivasi berpengaruh signifikan terhadap kinerja karyawan". Hasil penelitian ini didukung oleh Zameer et al. (2014) serta Shahzadi et al. (2014) bahwa motivasi berpengaruh signifikan terhadap kinerja karyawan. Hal ini juga sesuai dengan studi milik Omollo dan Oloko (2015), Christian et al. (2013) serta Ato'illah (2014), yang menyatakan bahwa motivasi memiliki hubungan yang signifikan dengan kinerja karyawan.

\section{KESIMPULAN}

Berdasarkan hasil dan pembahasan dalam penelitian ini, maka bisa disimpulkan sebagai berikut:

1. Ada pengaruh signifikan antara gaya kepemimpinan dengan kinerja karyawan Bank BJB Cabang Tangerang. Indikator pada gaya kepemimpinan yang memiliki mean tertinggi terdapat pada pernyataan "tidak ada kesempatan bagi bawahan untuk memberikan saran". Oleh karena itu, pemimpin yang dapat memotivasi karyawan akan dapat membentuk kinerja karyawan menjadi lebih baik.

2. Ada pengaruh signifikan antara motivasi terhadap kinerja karyawan Bank BJB Cabang Tangerang. Indikator pada motivasi yang mempunyai mean tertinggi terdapat pada pernyataan "merasa puas dengan gaji yang diberikan". Dengan demikian, indikator ini bisa meningkatkan kinerja karyawan Bank BJB menjadi lebih baik.

3. Indikator kinerja karyawan yang memiliki mean tertinggi ada pada pernyataan "memiliki kedisiplinan dalam setiap upaya melakukan pekerjaan". Dengan demikian, karyawan Bank BJB yang memiliki kedisiplinan yang baik dalam berkinerja.

Berdasarkan kesimpulan-kesimpulan yang telah diuraikan, ada beberapa saran untuk Bank BJB Cabang Tangerang agar menjadi perusahaan yang berkelanjutan dan untuk Akademisi, adalah:

1. Indikator gaya kepemimpinan yang mempunyai nilai mean terkecil ada pada pernyataan bahwa "pimpinan memberikan kesempatan bagi bawahan dalam proses pengambilan keputusan". Oleh karena itu, indikator ini perlu diperhatikan dan dievaluasi oleh Bank BJB, karena membuat kinerja karyawan akan menurun. 
Jika Bank BJB memberikan kesempatan karyawan untuk ikut berpartisipasi dalam pengambilan keputusan, maka akan meningkatkan kinerja karyawan sesuai dengan harapan masing-masing pemangku kepentingan.

2. Indikator motivasi yang mempunyai nilai mean terkecil ada pada pernyataan "penghargaan diri menjadi kebutuhan yang penting dalam bekerja". Oleh karena itu, indikator ini perlu diperhatikan dan dievaluasi oleh Bank BJB, karena membuat kinerja karyawan akan menurun. Jika Bank BJB memberikan penghargaan kepada karyawan yang mempunyai kinerja baik, maka akan membentuk sikap dan perilaku karyawan menjadi lebih baik dalam berkinerja.

3. Indikator kinerja yang mempunyai nilai mean terkecil ada pada pernyataan "jujur dalam melaksanakan segala pekerjaan”. Aspek ini dinilai sangat penting untuk mendapatkan perhatian, karena akan membuat kinerja karyawan menjadi menurun. Dengan demikian, Bank BJB perlu melakukan pelatihan pembentukan sikap dan perilaku positif agar dapat berlaku jujur dan adil terhadap terhadap semua pemangku kepentingan dan karyawan pada saat mengemban tugas dan pekerjaannya.

\section{DAFTAR PUSTAKA}

Abdilah, R.H.I.D. 2011. Analisis Pengaruh Gaya Kepemimpinan dan Motivasi Kerja terhadap Kinerja Karyawan (Studi pada Pegawai Badan Kesatuan Bangsa Politik dan Perlindungan Masyarakat Provinsi Jawa Tengah. Jawa Tengah). Skripsi. Semarang: Fakultas Ekonomi Universitas Diponegoro.

Agustina, D. 2015. Pengaruh Motivasi dan Gaya Kepemimpinan terhadap Kinerja Karyawan pada PDAM Tirta Benteng Kota Tangerang. Skripsi. Jakarta: Universitas Mercu Buana.

Amalia, D.R., Swasto, B. dan Susilo, H. 2016.

Pengaruh Gaya Kepemimpinan ter- hadap Motivasi Kerja dan Kinerja Karyawan pada Karyawan Pabrik Gula Kebon Agung Malang. Jurnal Administrasi Bisnis. Vol. 36, No. 1, hal. 137-146.

Arimbawa, I.K.M. dan Dewi, A.A.K. 2013. Pengaruh Budaya Organisasi, Gaya Kepemimpinan dan Motivasi Kerja terhadap Kinerja Karyawan pada Hotel Jimbaran Puri Bali. E-Jurnal Manajemen Universitas Udayana. Vol. 2, No. 12, hal. 1693-1710..

Ato'Illah, M. 2014. Analisis Pengaruh Gaya Kepemimpinan dan Motivasi terhadap Kinerja Pegawai Kelurahan di Kecamatan Lumajang Kabupaten Lumajang. Jurnal WIGA. Vol. 4, No. 1, hal. 1-18..

Babatunde, O. dan Emem, I. 2015. The Impact of Leadership Style on Employee's Performance in an Organization. Public Policy and Administration Research, Vol. 5, No. 1, hal. 193-205.

Bank BJB. 2016. Sekilas Bank BJB. http://www.bankbjb.co.id/id/corporate -website/hubungan-investor/tentangbank-bjb/sekilas-bank-bjb.html

Fahmi, I. 2013. Pengantar Manajemen Keuangan. Bandung: Alfabeta.

Fuad, M., Nurbaya, S. dan Amirullah. 2017. Pengantar Bisnis. Yogyakarta: Indomedia Pustaka.

Ghozali, I. 2011. Aplikasi Analisis Multivariate dengan Program IBM SPSS 19. Semarang: Badan Penerbit Universitas Diponegoro.

2013. Aplikasi Analisis Multivariate dengan Program IBM SPSS 21. Cetakan Ketujuh. Semarang: Badan Penerbit Universitas Diponegoro.

Green, S.B. 1991. How Many Subjects does It Take to Do a Regression Analysis? Multivariate Behavioral Research, Vol. 26, No. 3, hal. 499-510.

Hartanto, A. 2016. Analisis Gaya Kepemimpinan pada PT. Sinar Sarana Sukses. Agora. Vol. 4, No. 2, hal. 140-145. 
Hasibuan, M.S.P. 2009. Manajemen Sumber Daya Manusia. Jakarta: PT. Bumi Aksara.

HRD Bank BJB Indonesia Cabang Tangerang. 2016. Kehadiran Karyawan dari Tahun 2013 hingga September 2016. Tangerang.

Iqbal, N., Anwar S. dan Haider N. 2015. Effect of Leadership Style on Employee Performance. Arabian Journal of Business and Management Review. Vol. 5, No. 5, hal. 1-6.

Kiruja, E.K. dan Mukur, E. 2013. Effect of Motivation on Employee Performance in Public Middle Level Technical Training Institutions in Kenya. International Journal of Advances in Management and Economics, Vol. 2, No. 4, hal. 73-82.

Krisnadi, A. dan Tarigan, J.. 2016. Pengaruh Gaya Kepemimpinan terhadap Kinerja Keuangan melalui Perilaku Manajer atas Isu Manajemen Lingkungan sebagai Variabel Intervening. Business Accounting Review. Vol. 4, No. 1, hal. 169-180.

Luthans, F. 2009. Perilaku Organisasi. Edisi Sepuluh. Yogyakarta: Andy Offset.

Mangkunegara, A.P. 2009. Evaluasi Kinerja SDM. Cetakan Keempat. Bandung: PT. Refika Aditama. 2010. Evaluasi Kinerja SDM. Cetakan Kelima. Bandung: PT. Refika Aditama.

Notoadmodjo, S. 2009. Pengembangan Sumber Daya Manusia. Jakarta: Rineka Cipta.

Omollo, P.A. dan Oloko. 2015. Effect of Motivation on Employee Performance of Commercial Banks in Kenya: A Case Study of Kenya Commercial Bank in Migori County. International Journal of Human Resource Studies. Vol. 5, No. 2, hal. 87-103.

Paracha, M.U., Qamar, A., Mirza, A., Hassan, I.U. dan Waqas, H. 2012. Impact of Leadership Style (Transformational \& Transactional Leadership) on Employee Performance \& Mediating Role of Job Satisfaction Study of
Private School (Educator) in Pakistan Global. Journal of Management and Business Research, Vol. 12, No. 4, hal. 55-64.

Rivai, V. 2008. Kepemimpinan dan Perilaku Organisasi. Edisi Kedua. Jakarta: PT. RajaGrafindo Persada.

Rivai, V. dan Sagala, E.J. 2010. Manajemen Sumber Daya Manusia untuk Perusahaan. Jakarta: PT. Raja Grafindo Persada.

Roscahyo, A. 2013. Pengaruh Gaya Kepemimpinan terhadap Kinerja Karyawan Pada Rumah Sakit Siti Khodijah Sidoarjo. Jurnal Ilmu \& Riset Manajemen. Vol. 2, No. 12, hal. 116.

Sanusi, A. 2011. Metodologi Penelitian Bisnis. Jakarta: Salemba Empat.

Shahzadi, I., Javed, A., Pirzada, S.S., Nasreen, S. dan Khanam, F. 2014. Impact of Employee Motivation on Employee Performance. European Journal of Business and Management. Vol. 6, No. 23, hal. 159-166.

Simanjuntak, P.J. 2005. Manajemen dan Evaluasi Kerja. Jakarta: Lembaga Penerbit FEUI.

Sudjiman, P.E.. 2009. Manajemen dan Kepemimpinan. Jurnal Sekretari. Vol. 1, No. 1, hal. 37-44.

Sugiyono. 2012. Metode Penelitian Bisnis. Bandung: CV. Alfabeta.

Sutrisno, E. 2010. Manajemen Sumber Daya Manusia. Cetakan Kedua. Jakarta: Prenada Media Group. 2009. Manajemen Sumber Daya Manusia. Cetakan Pertama. Jakarta: Prenada Media Group.

Thoha, M. 2005. Perilaku Organisasi. Edisi Pertama. Jakarta: PT. RajaGrafindo Persada.

Turang, R.C., Kindangen, P. dan Tumiwa, J. 2013. Influence of Leadership Style, Motivation, and Work Discipline on Employee Performance in PT. Dayana Cipta. Jurnal Berkala Ilmiah Efisiensi. Vol. 15, No. 4, hal. 505516. 
Wirawan. 2013. Kepemimpinan: Teori, Psikologi, Perilaku Organisasi, Aplikasi dan Penelitian. Edisi Pertama. Jakarta: PT. RajaGrafindo Persada.

Zameer, H., Ali, S., Nisar, W. dan Amir, M. 2014. The Impact of the Motivation on the Employee's Performance in Beverage Industry of Pakistan. International Journal of Academic Research in Accounting, Finance and Management Sciences. Vol. 4, No. 1, hal. 293-298. 